\title{
Cooperative Learning in Nursing Education: A Review
}

\author{
Raymol Rahel Abraham
}

Assistant Lecturer, K. J. Somaiya School \& College of Nursing, Sion (E), Mumbai- 400022, Maharashtra, India.

\begin{abstract}
Nurses are the backbone of the healthcare team. They must be able to work cooperatively with the other members of the health team and should use their critical thinking and analytical skills in the clinical area. Nursing education must use active learning strategies to equip the student nurses with these abilities. Cooperative learning methods can ensure active participation of the student nurses in the teaching learning process. This article reviews the scope of cooperative learning methods in Nursing education and its advantages for the Nursing students.
\end{abstract}

Key words: Cooperative learning, Nursing education, Nursing students.

\section{INTRODUCTION}

Nursing is a challenging job and the nurse needs to keep herself updated to be in pace with the advancements in healthcare. Nurse educators play the vital role in preparing student nurses with critical thinking, high interests in profession and high proficiency in patient care. They have to make sure that the students are well equipped to handle the demand for specialized care when they graduate as fullfledged nurses. With all the time constraints, the administrative responsibilities and the amount of teaching and clinical postings to cover, it can be overwhelming for the nurse educators to concentrate on individual student. Use of cooperative learning model can be a solution as learning with the group can maximise the learning effect. This is a teaching model that has received little attention in nursing. ${ }^{1}$

\section{Concept}

Cooperative learning is a type of group learning in which the students form small groups and work together. They encourage each other to learn and succeed. The group members motivate each other to learn as the achievement of the group is dependent on the individual learning of all the members. The major component of cooperative learning is the peer interaction in the process of learning and thinking. The methods help not only intellectual development but also the development of social skills. Team work which is an essential part of health care can be taught by this model. ${ }^{1}$

The role of a teacher in cooperative learning is different from traditional methods. Students are the constructors of knowledge and teachers, the facilitators. The teacher acts like a friend and a guide. Cooperative learning facilitates higher order learning abilities like analysis and critical thinking which are essential for practicing nurses ${ }^{2}$.

\section{Elements}

The basic elements of cooperative learning are:

1. Positive interdependence

2. Individual accountability

3. Social skills

4. Group processing

5. Promotive interaction.

Each element plays its own role in the overall development of the students in the model of cooperative learning ${ }^{3}$.

A cooperative learning environment requires proper structuring of the groups to 
facilitate learning. The members in each groups must be limited to 4-6. Sitting arrangement must be such that the members face each other. This can facilitate effective group interaction. The teacher can plan activities outside the classroom too. ${ }^{4,5}$

It is equally important to orient the students to the new learning method before implementing it for better cooperation from them. A collaborative study done to find out the issues faced by the nurse educators brought out the following aspects: students did not understand the need for structured cooperative learning; classroom structure and seating arrangement influenced the effectiveness of activities; highly structured activities engaged the students; and short, targeted activities that involved novel content were most effective. These findings enforce the need for the structuring of activities and preparation of students in cooperative learning ${ }^{6}$.

\section{Advantages}

Cooperative learning model can provide several benefits for the Nursing students. It helps in the development of higher level thinking, communication skills, self-management and leadership skills. Students learn to take up responsibility and be accountable for whatever is done individually and as a group. They acquire the skill of shared leadership. The cooperative interdependence in the groups helps the slow learners also to accomplish their goals. It establishes a "swim or sink together" learning experience.

Cooperative learning model can be used not only for teaching the student nurses but also for the training of practice nurses and newly registered nurses. A study done on 130 practice nurses and 80 newly recruited nurses in Hunan Province showed a significant improvement in the theoretical knowledge and clinical skills. Cooperative learning also improved their learning initiative, awareness of cooperation, ability to think, communication skills and comprehensive ability. ${ }^{7}$
Nursing is a field which requires lifelong learning. Cooperative learning method can improve students' self-esteem as well as attitude towards learning. A quasi experimental study done on 61 students from Saudi Arabia indicated improvement in the self-esteem and attitude towards learning. The study suggested cooperative learning as an instructional pedagogy for lifelong learning. ${ }^{8}$

Nurse educators have a major role in building confidence in the students to perform procedures on the patients. They have to use active learning strategies to help students acquire and utilize critical thinking skills in the clinical area. Several studies showed positive impact of cooperative learning strategies on acquisition of knowledge and skills. Comparison of cooperative learning with individual learning among ninety-eight Nursing students in Taiwan revealed better acquisition of knowledge among the cooperative learning group. ${ }^{9}$

Effective communication between the nurse and the patient is an essential component of nursing care. Cooperative learning is an effective method for improving and increasing communication skills of nursing students especially interactive skills, according to a study done in Iran. Small groups facilitate face to face interaction and build confidence in students to communicate better. Group members reflect upon the situations which hindered their performance. This give them chance to improve and grow. ${ }^{10}$

\section{Cooperative learning strategies}

A variety of cooperative learning strategies are used in the education field. The common ones include: Think-pairshare, stir the class, four corner strategy, fish bowl, numbered heads together, round table, group investigation, jigsaw and Student Teams Achievement Division (STAD).

Jigsaw method is the popular one implemented in nursing education. In Jigsaw method the students are members of two groups: the base group and the expert 
group. Each expert group is given a topic which the members discuss and study. They go back to their base group and teach the members whatever they have learnt from the expert group. Thus each member is accountable for teaching the base group the topic assigned to them.

Many studies support Jigsaw method as an efficient tool in Nursing education. A review study revealed that the benefits of Jigsaw method include an increase in motivation, enjoying learning, learning achievement, self-confidence, and selfesteem, refreshment of information, interest, and communication. The study also suggested that this method can be used in different disciplines of education such as Medicine, Nursing, Pharmacy, English, Physics, Mathematics etc. ${ }^{11}$ Other studies on Jigsaw showed that it is useful in only in improving communication skills but also in developing empathy and self-directed learning. . $^{2,13,14}$ It is also proved as an effective tool to improve the knowledge level of Nursing students. ${ }^{15}$

\section{CONCLUSION}

Going through the different studies in the field of Nursing Education leads to the conclusion that cooperative learning is an effective method for training nurses as it can improve their critical thinking, analysing ability, social and communication skills, problem solving and positive emotional state, which are highly required skills in the nursing profession. The literature review also shows the need for more researches in this field as the evidence available is limited.

\section{Acknowledgement: None}

\section{Conflict of Interest: None}

\section{Source of Funding: None}

\section{REFERENCES}

1. Cynthia Huff, Cooperative learning: A model for teaching, Journal of Nursing education, 1997; 36(9): 434-436. Available from https://doi.org/10.3928/0148-483419971101-09

2. Qais Faryadi, Enlightening Advantages of Cooperative Learning, 2007:1-10. Available from https://files.eric.ed.gov/fulltext/ED495702.p df

3. Alexis Howlett, The Basic Elements of Cooperative Learning, Teaching and learning in 2015. Available from https://sites.google.com/a/odu.edu/teachinglearning-in-2015/home/content/section-3effective-teaching/instructional-theoriesand-practices/elements-of-cooperativelearning

4. Van Dat Tran, Theoretical perspectives underlying the application of cooperative learning in classrooms, International journal of higher education, 2013; 2(4): 101-115. Available from https://files.eric.ed.gov/fulltext/EJ1067527.p df

5. Robyn M. Gillies, Cooperative learning: Review of research and practice, Australian Journal of Teacher Education, 2016; 41(3), 39-54. Available from https://www.researchgate.net/publication/30 0003670_Cooperative_Learning_Review_of _Research_and_Practice

6. Marilyn Smith-Stoner, Mary E. Molle, Collaborative Action Research: Implementation of Cooperative Learning, Journal of Nursing Education. 2010;49(6):312-318. Available from https://www.healio.com/nursing/journals/jne /2010-6-49-6/\% 7Bbffd77c3-dde9-4f9fb4ba-a1bbd755c0d0\%7D/collaborativeaction-research-implementation-ofcooperative-learning\#divReadThis

7. Li Yang, Donghua Jiang, Hanzhu Nie, Siyuan Tang, Research on the effect of cooperative learning model on nursing skills of practice nurses and standardized training of newly-recruited nurses, Biomedical Research,2018; 29(9). Available from https://www.alliedacademies.org/articles/res earch-on-the-effect-of-cooperative-learningmodel-on-nursing-skills-of-practice-nursesand-standardized-training-of-newlyrecrui10224.html\#: :text=Cooperative\%20learnin g\%20model\%20emphasizes\%20the,signific ant $\% 20$ learning $\% 20$ effects $\% 20 \% 5 \mathrm{~B} 7 \% 5 \mathrm{D}$

8. Mona M. Megahed, Fathia A. Mohammad Effect of cooperative learning on undergraduate nursing students' self-esteem: 
A quasiexperimental study, Journal of Nursing education and practice. 2014;4(11): 1-7. Available from http://www.sciedu.ca/journal/index.php/jnep /article/view/4526/3185

9. Zu-ChunLin, Comparison of technologybased cooperative learning with technologybased individual learning in enhancing fundamental nursing proficiency, Nurse Education Today, May 2013;33(5): 546551. Available from https://www.sciencedirect.com/science/artic le/abs/pii/S0260691711003406

10. Nayereh Baghcheghi, Hamid Reza Koohestani, KoreshRezaei, A comparison of the cooperative learning and traditional learning methods in theory classes on nursing students' communication skill with patients at clinical settings,Nurse Education Today, November 2011; 31(8):877-882. Available from https://www.sciencedirect.com/science/artic le/abs/pii/S0260691711000190

11. Karimi Moonaghi, H., Bagheri, M. Jigsaw: A good student-centered method in medical education. Future of Medical Education Journal, 2017; 7(1): 35-40. Available from https://fmej.mums.ac.ir/article_8757.html

12. Park, Jeong-Hye, Effectiveness of Cooperative Learning on Nursing Students' Performance and Experience, The Journal of Korean Academic Society of Nursing Education, 2010; 16 (2), 202-212. Available from
http://www.koreascience.or.kr/article/JAKO 201001862092459

13. Sudha devi M. Jigsaw- a teaching strategy, American Journal of Advances in Nursing Research. 2018;5(1):29-31. Available from http://mcmed.us/downloads/1513147255(aja nr).pdf

14. Sumitra Melinamani, Frincy Francis, Reena George, L Mariya Pushpa, Shilpa Vergheese, The Jigsaw effect: Impact of Jigsaw learning technique on nursing students to learn the concepts of normal labor, Asian J. Nursing Edu. and Research, April- June 2017; 7(2): 1-5 file://C:/Users/24004133/Downloads/AJNE R-632--12-05-2016-Revised-18-52016....R.pdf

15. Mrs. Lakshmi Renganathan, A Comparative study on Effect of Jigsaw Puzzle Method among nursing students' academic level of performance at Oman Nursing Institute, Indian journal of applied research, Sept 2013; 3(9):180- 182. Available from https://www.worldwidejournals.com/indianjournal-of-applied-research-

(IJAR)/recent_issues_pdf/2013/September/S eptember_2013_1493044103_57.pdf

How to cite this article: Abraham RR. Cooperative learning in nursing education: a review. International Journal of Research and Review. 2021; 8(4): 484-487. DOI: https://doi. org/10.52403/ijrr.20210458 